\title{
Association among serum and salivary A. actinomycetemcomitans specific immunoglobulin antibodies and periodontitis
}

Gaetano Isola ${ }^{1 *}\left(\mathbb{D}\right.$, Alessandro Polizzi $^{1}$, Romeo Patini $^{2}$, Sebastiano Ferlito ${ }^{1}$, Angela Alibrandi ${ }^{3}$ and Giuseppe Palazzo ${ }^{1}$

\begin{abstract}
Background: The aim of this study was to assess the association between serum and salivary Immunoglobulin (lg) Aggregatibacter actinomycetemcomitans (A. actinomycetemcomitans) specific antibodies in healthy controls (HC) and periodontitis (PT) patients. Furthermore, the objectives were to determine whether PT influenced serum $A$. actinomycetemcomitans specific antibodies and whether serum or salivary antibodies against $A$. actinomycetemcomitans lgG were mediated by serum high-sensitivity c-reactive protein (hs-CRP).

Methods: Fifty-three patients with periodontitis and $48 \mathrm{HC}$ were enrolled in the present study. Patients were regularly examined and characterized by clinical, salivary and blood samples analyses. A. actinomycetemcomitans IgA and IgG antibodies and hs-CRP were evaluated using a commercially available kit. The Spearman Correlation Test and Jonckheere-Terpstra Test were applied in order to assess the interdependence between serum $A$. actinomycetemcomitans lgG antibodies and clinical periodontal parameters. To evaluate the dependence of the serum and salivary A. actinomycetemcomitans lgG levels from possible confounders, univariate and multivariable linear regression analyses were performed.

Results: Compared to HC, patients with PT had significantly higher lgA [serum: PT, 1.89 (1.2-2.2) EU vs HC, 1.37 $(0.9-1.8) \mathrm{EU}(p=0.022)$; saliva: PT, $1.67(1.4-2.1) \mathrm{EU}$ vs HC, $1.42(0.9-1.6) \mathrm{EU}(p=0.019)]$ and $A$. actinomycetemcomitans IgG levels [serum: PT, 2.96 (2.1-3.7) EU vs HC, 2.18 (1.8-2.1) EU ( $p<0.001)$; saliva, PT, 2.19 (1.8-2.5) EU vs HC, 1.84 (1.4-2) EU ( $p=0.028)]$. In PT patients, serum A. actinomycetemcomitans IgG were associated with a proportional extent of PT and tooth loss (P-trend value $<0.001$ ). The univariate regression analysis demonstrated that PT $(p=0.013)$ and high hs-CRP $(p<0.001)$ had a significant negative effect on serum and salivary A. actinomycetemcomitans IgG levels. The multivariate regression analysis showed that PT ( $p=0.033)$, hs-CRP ( $p=$ $0.014)$ and BMI $(p=0.017)$ were significant negative predictors of serum A. actinomycetemcomitans IgG while hs-CRP $(p<0.001)$ and BMI $(P=0.025)$ were significant negative predictors of salivary $A$. actinomycetemcomitans lgG.

(Continued on next page)
\end{abstract}

\footnotetext{
* Correspondence: gaetano.isola@unit.it

${ }^{1}$ Department of General Surgery and Surgical-Medical Specialties, School of Dentistry, University of Catania, Via S. Sofia 78, 95124 Catania, Italy

Full list of author information is available at the end of the article
}

(c) The Author(s). 2020 Open Access This article is licensed under a Creative Commons Attribution 4.0 International License, which permits use, sharing, adaptation, distribution and reproduction in any medium or format, as long as you give appropriate credit to the original author(s) and the source, provide a link to the Creative Commons licence, and indicate if changes were made. The images or other third party material in this article are included in the article's Creative Commons licence, unless indicated otherwise in a credit line to the material. If material is not included in the article's Creative Commons licence and your intended use is not permitted by statutory regulation or exceeds the permitted use, you will need to obtain permission directly from the copyright holder. To view a copy of this licence, visit http://creativecommons.org/licenses/by/4.0/. The Creative Commons Public Domain Dedication waiver (http://creativecommons.org/publicdomain/zero/1.0/) applies to the data made available in this article, unless otherwise stated in a credit line to the data. 
(Continued from previous page)

Conclusions: PT patients presented a significantly higher serum and salivary A. actinomycetemcomitans IgA and IgG compared to HC. There was a significant increase in serum A. actinomycetemcomitans IgG when patients presented a progressive extent of PT. Moreover, PT and hs-CRP were significant negative predictors of increased salivary and serum A. actinomycetemcomitans lgG levels.

Trial registration: The study was retrospectively registered at clinicaltrials.gov (NCT04417322).

\section{Background}

Personalized dentistry is an ongoing multidisciplinary model which is aimed at tailoring healthcare with dental research, practice and decisions specifically customized for the single patient [1]. In this model, diagnostic tests are usually applied for the approach to periodontitis (PT) for selecting optimal and appropriate therapies on the specific patient's context through a genetic subject or other physiological, epidemiological, or molecular analyses [2].

PT is a chronic inflammatory disease correlated with a plethora of systemic disorders such as endothelial dysfunction [3], diabetes [4], and metabolic syndrome [5]. PT is mainly caused by pathogenic pathogens organized in biofilm which, due to the host inflammatory response, results in periodontal tissues destruction, bone resorption and finally in tooth loss [6].

Of the main periodontal pathogens, during the last few decades, an important role in the aetiology and progression of PT has been shown mainly by certain bacteria, such as Tannerella forsythia, Porphyromonas gingivalis (P. gingivalis), and Aggregatibacter actinomycetemcomitans (A. actinomycetemcomitans) [7, 8]. The presence of these bacteria has been demonstrated, in periodontal tissues, to stimulate the first innate host tissue response against the release of host inflammatory mediators from the junctional epithelium and from the fibroblasts, macrophages and neutrophils activated by lymphocytes which in term, could finally lead to periodontal tissue destruction and tooth loss $[9,10]$.

A. actinomycetemcomitans is a facultative Gramnegative bacterium considered to have a key role in PT development due to its important orchestration of the gingival dysbiosis during the early stages of disease [11]. Several reports have highlighted high serum immunoglobulin (Ig) -A and IgG antibodies levels against A. actinomycetemcomitans in the early stages of some diseases, such as cardiovascular diseases [12], diabetes [13] and rheumatoid arthritis [14]. For these reasons, it is conceivable to find biomarkers which could help to understand the aetiology of PT better and to prevent riskrelated factors associated with PT.

Moreover, some cohort studies have highlighted the strict role of periodontal bacteria and a positive association among $A$. actinomycetemcomitans antibody levels and coronary artery calcification [13]. All of these studies have shown that the exclusive presence of some pathogens such as A. actinomycetemcomitans and P. gingivalis at gingival level represents the main determinant of a systemic antibody response by the host, suggesting that serology may mark the history of past and present periodontal infection [15]. Some reports have shown that serum antibody levels against pathogenic periodontal bacteria remain stable over time [15], while they decrease only transiently after the treatment of PT [16], with significant a significant association with the progression of PT [17].

Based on these findings, this study was aimed at further analyzing the relationship between serum Ig antibodies against $A$. actinomycetemcomitans antibodies and PT and to explore the main predictors that can influence gingival health in PT and healthy subjects. Additionally, the purposes were 1) to evaluate the impact of PT on the serum and salivary IgG antibodies against A. actinomycetemcomitans; 2) whether there was an association between serum and salivary IgG antibodies against $A$. actinomycetemcomitans; 3) whether hs-CRP had a significant influence on serum and salivary IgG antibodies against $A$. actinomycetemcomitans.

\section{Methods \\ Study design}

A number of 221 subjects were enrolled from May 2016 to December 2019 at the School of Dentistry of the University of Messina, Messina, Italy. The local International Review Board (IRB) approved the protocol of the study prior to the patient's enrolment (\#12-16). The trial was registered at clinicaltrials.gov (NCT04417322). All enrolled subjects were carefully instructed on the study characteristics and who then gave their written informed consent. The study was performed in accordance with the Declaration of the World Medical Association 1975 in Helsinki guidelines, revised in 2000 and followed the STROBE (Strengthening The Reporting Of Observational Studies In Epidemiology) guidelines (Additional file 1).

Group of patients were selected on sex and on a specific age range (from 35 to 65 years old) in order to obtain a similar proportion of cases on categories, sex and age, defined by the selection variable. A total of $48 \%$ of patients were males ranging in age from 41 to 57 years old. 
Sociodemographic parameters such as gender, age, and a complete medical history and medications were recorded at baseline in all enrolled subjects by the same calibrated clinician. Subsequently, each patient underwent an oral assessment and a periodontal charting by the recording, at six sites per tooth by means of standard periodontal parameters [18] using a manual periodontal probe (PCP-15; Hu-Friedy, Milan, Italy).

The diagnosis of PT was performed, as 1) having a number of teeth $\geq 16$; 2 ) having at least $40 \%$ of periodontal sites with bleeding on probing (BOP), a probing depth $(\mathrm{PD}) \geq 4 \mathrm{~mm}$ and clinical attachment level $(\mathrm{CAL}) \geq$ $2 \mathrm{~mm}$ [6]; 3) having $\geq 2 \mathrm{~mm}$ of interdental alveolar bone loss verified through Rinn radiographs [3].

Healthy subjects, matched for gender and age, had no systemic disease, did not take any drugs, and presented good oral health and had no sites with $\mathrm{PD} \geq 4 \mathrm{~mm}$ or $\mathrm{CAL} \geq 4 \mathrm{~mm}$ and there $\mathrm{X}$-rays did not show any signs of bone loss; consequently, these patients were enrolled as healthy control group.

The exclusion criteria for all patients were: (1) consumption of contraceptive drugs; (2) consumption of immunosuppressive, antibiotics or anti-inflammatory at least the previous 3-months preceding the study; (3) status of pregnancy or lactation; (4) history of drinking; (5) allergy episodes to drugs or local anaesthetics; (6) consumption of any drugs that could give gingival hyperplasia.

\section{Study population}

The present trial was designed as a cross-sectional study. After a preliminary screening, 120 subjects were initially excluded because they did not present all inclusion criteria $(n=94)$, declined to participate $(n=15)$ or were absent at the first visit $(n=11)$. Finally, a number of 53 patients with PT and 48 healthy subjects were analyzed (Fig. 1).

\section{Data collection}

At the first visit, the sociodemographic characteristics of the enrolled patients such as age, gender, body mass index (BMI), anamnesis and medications were recorded. BMI was valued by calculating the patient's weight and height. Diagnosis of diabetes mellitus was determined, at this stage, with the presence of a fasting blood glucose $\geq 7 \mathrm{mmol} / \mathrm{l}$. The presence of any oral disorder, if present, was recorded during this phase.

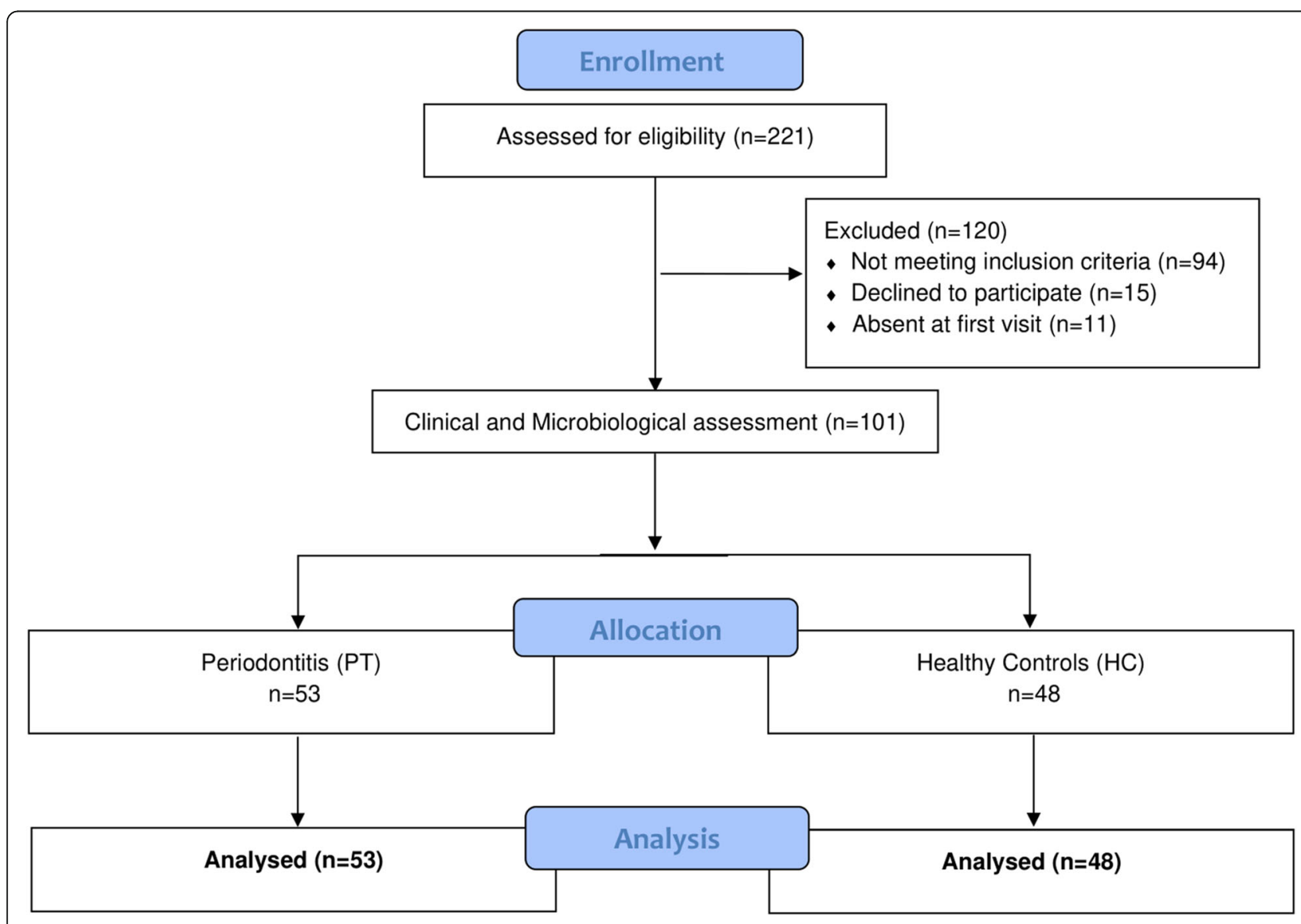

Fig. 1 Flowchart of the study 
The oral assessment included, at six sites per tooth, the recording of clinical periodontal indexes such as PD, CAL, BOP and plaque score (PI) [19]. BOP was registered by the appearance of gingival bleeding after probing up to $30 \mathrm{~s}$ during $\mathrm{PD}$ assessment. CAL was documented as PD plus the presence of gingival recession, using the cementoenamel junction as reference.

The inter-examiner reliability test was performed calculating the intraclass correlation coefficient (ICC) and demonstrated a good degree of reliability for CAL $(\mathrm{ICC}=0.824)$. The intra-examiner reliability was performed, for the principal and control examiners, on 6 patients randomly chosen per group. The variable CAL recorded resulted in a good agreement both for the principal $(\mathrm{ICC}=0.827)$ and control $(\mathrm{ICC}=0.829)$ examiner.

\section{Laboratory analyses}

During the first examination, the serum and saliva sampling was performed on each patient by the same examiner between 8.00 and 9.00 am (A.P.). Each patient was asked to avoid eating, drinking and brushing their teeth during the $12 \mathrm{~h}$ preceding plasma and saliva sampling. For the collection of saliva, cotton rolls were used which were chewed for two minutes by the patient using a specific kit (Salivette ${ }^{\bullet}$, Sarsted, Verona, Italy). Immediately after, the salivary and serum samples were centrifuged at $4{ }^{\circ} \mathrm{C}$ (1000 xg for $2 \mathrm{~min}$ ). After sampling, blood samples were stored at $-80^{\circ} \mathrm{C}$, and saliva samples at $-20^{\circ} \mathrm{C}$. In all patients, all analyses were achieved at the same centre after overnight fasting. Glucose, fibrinogen, and plasma lipids levels were obtained by routine laboratory analysis. The hs-CRP was measured using a nephelometric assay kit and expressed in milligrams per decilitres ( $\mathrm{mg} / \mathrm{dl})$.

All serum and saliva samples were diluted with PBS to a 1:100 ratio as previously shown [20]. For serum and saliva samples for IgG antibodies, $100 \mu \mathrm{l}$ of each diluted serum and saliva sample was added to individual well and incubated for $1 \mathrm{~h}$ at room temperature. $100 \mu \mathrm{l}$ of IgG conjugate was added to each well and incubated at room temperature for $1 \mathrm{~h}$ (Goat Antihuman IgG HRP 1: 5000 concentration using a blocking buffer) using ELISA kit (R\&D Systems, Minneapolis, MN, and SigmaAldrich, St Louis, MO). The lower limit of the assay was $0.005 \mathrm{ng} / \mathrm{mL}$. $100 \mu \mathrm{l}$ of sulphuric acid $\left(\mathrm{H}_{2} \mathrm{SO}_{4}\right)$ stop solution was then added to stop the reaction and the optical density was taken at $450 \mathrm{~nm}$ into iMARK microplate reader. Based on optical density, values were calculated for serum and salivary IgG antibodies (iMARK microplate reader, BIORAD, Hercules, California). For serum and saliva samples for IgA antibodies, samples were diluted with PBS to 1:100 (serum) and 1:50 (saliva) ratios. $100 \mu \mathrm{l}$ of IgA conjugate (Goat Antihuman IgA Peroxidase 1:10,000 concentration using a blocking buffer) was added to each well and incubated for $1 \mathrm{~h}$ at room temperature. $100 \mu \mathrm{l}$ of sulfuric acid $\left(\mathrm{H}_{2} \mathrm{SO}_{4}\right)$ stop solution was then added to stop the reaction and the optical density taken at $450 \mathrm{~nm}$ into iMARK microplate reader. For the assays, the antigens contained a mixture of strains representing six serotypes of $A$. actinomycetemcomitans. The strains were (a) ATCC 29523, (b) ATCC 43718, (c) ATCC 33384, (d) IDH 781, (e) IDH 1705, and (f) C59A $[21,22]$. The final levels of pathogen-specific immunoglobulins were normalized in accordance with the serum samples reference and were expressed in ELISA units (EU). The coefficient of interassay variation was $4.1 \%$ for serum $A$. actinomycetemcomitans IgG and $4.2 \%$ for A. actinomycetemcomitans IgA, as previously reported [22].

\section{Sample size analysis}

The sample size analysis was determined before the study by considering two groups of patients, an effect size of 0.27 for serum $A$. actinomycetemcomitans IgG (primary outcome chosen), an expected standard deviation of 0.5 [20], a two-sided significance of 0.05 and a power of $80 \%$. It was established that at least 44 subjects per single group were required for a good power sample level. In each group around 48 people were finally enrolled, so that a power value of $81 \%$ was obtained.

\section{Statistical analysis}

For the statistical analysis, numerical data is represented as median and interquartile range or mean \pm standard deviation (SD), and number and percentage for categorical variables. For data, a non-parametric approach was chosen because most examined variables did not have a normal distribution, such as that verified by the Kolmogorov Smirnov test. In order to compare the numerical data in the two groups, the Mann-Whitney test was applied.

The non-parametric Spearman correlation test was applied in order to establish any significant interdependence between A. actinomycetemcomitans IgG and periodontal parameters analyzed in all enrolled patients and then for a single group. The same test was used to evaluate significant interdependence between serum and salivary A. actinomycetemcomitans IgG versus hs-CRP. Furthermore, to analyze the association among diabetes (expressed such as yes/no) and A. actinomycetemcomitans IgG, a biserial point correlation was used.

Periodontal parameters are represented with mean \pm $\mathrm{SD}$ and the comparisons between groups (periodontitis and controls) with the relative $p$-value. In order to assess whether periodontal parameters were influenced (increasing or decreasing) with a A. actinomycetemcomitans IgG increase, p-trend quartiles of $A$. actinomycetemcomitans IgG levels were obtained, and for each quartile of A. actinomycetemcomitans IgG, a mean and standard deviation $( \pm S D)$ of all periodontal parameters was 
calculated. The Jonckheere-Terpstra Test was applied for the main analyzed periodontal variables to evaluate a p-trend for ordered quartiles of A. actinomycetemcomitans IgG. In particular, the Jonckheere-Terpstra Test was performed to determine whether serum and salivary A. actinomycetemcomitans IgG were statistically increased in the analyzed groups.

A stepwise multivariable linear regression model was used in order to analyze the dependence of every single periodontal parameter by explicable variables as gender, age, BMI, serum and salivary $A$. actinomycetemcomitans IgA, A. actinomycetemcomitans IgG, hs-CRP, highdensity lipoprotein (HDL) and low-density lipoprotein (LDL) cholesterol.

Moreover, univariate and multivariable linear regression analyses were performed to evaluate the dependence of serum A. actinomycetemcomitans IgG levels (which were normally distributed) by possible predictors including age, sex, educational level, socioeconomic status (SES), smoking (yes/no), triglycerides, LDL cholesterol, HDL cholesterol, and taking into account possible confounders such as periodontitis, BMI and hs-CRP. The same regression analysis was performed for salivary A. actinomycetemcomitans IgG levels. Among possible predictors, serum A. actinomycetemcomitans IgG levels was also added. A two-sided $P$-value $<0.05$ was considered to be statistically significant. All statistical analyses were made using a statistical software program (SPSS 22.0 for the Windows package; SPS Srl, Bologna, Italy).

\section{Results}

\section{Patients characteristics}

Demographic characteristics of the enrolled patients are represented in Table 1. All patients were Caucasians and were well matched for age $(p=0.076)$, gender $(p=$ $0.149)$, BMI $(p=0.082)$ and number of smoking subjects $(p=0.119)$ (Table 1). PT patients presented higher median hs-CRP values $[0.58(0.37-0.69) \mathrm{mg} / \mathrm{dl}]$ in comparison with healthy controls $[0.36(0.28-0.41) \mathrm{mg} / \mathrm{dl}](p<$ 0.001) (Table 1).

Analysis of periodontal parameters comparisons is represented in Table 2. PT patients had a significantly lower number of teeth and higher levels of PD, CAL and BOP compared to healthy subjects $(\mathrm{p}<0.001)$, while the PI score was similar between groups $(p=0.108)$.

\section{Primary outcomes results}

Compared to $\mathrm{HC}$, patients with $\mathrm{PT}$ had significantly higher IgA [serum: PT, $1.89(1.2-2.2) \mathrm{EU}$ vs HC, 1.37 (0.9-1.8) EU ( $p=0.022)$; saliva: PT, 1.67 (1.4-2.1) EU vs $\mathrm{HC}, 1.42(0.9-1.6) \mathrm{EU}(p=0.019)]$ and A. actinomycetemcomitans IgG levels [serum: PT, $2.96(2.1-3.7)$ EU vs HC, $2.18(1.8-2.1)$ EU $(p<0.001)$; saliva, PT, 2.19 (1.82.5) EU vs HC, 1.84 (1.4-2) EU $(p=0.028)$ ] (Table 1).
No significant association was found between serum and salivary $A$. actinomycetemcomitans IgG levels $\left(\mathrm{r}_{\mathrm{s}}=\right.$ $0.198, p=0.294$ ).

The Spearman correlation analysis highlighted that, in all patients, serum A. actinomycetemcomitans IgG levels presented a negative correlation with the number of teeth (coeff. $=-0.546, p<0.001$ ) and a positive correlation with high levels of hs-CRP (coeff. $=0.431, \mathrm{p}<$ 0.001 ), BOP (coeff. $=0.306, \mathrm{p}<0.001$ ), PD (coeff. $=0.299$, $\mathrm{p}<0.001$ ), CAL (coeff. $=0.556, \mathrm{p}<0.001$ ), and PI (coeff. 0.673, p < 0.001) (Fig. 2). Regarding salivary A. actinomycetemcomitans IgG, there was a negative correlation with the number of teeth (coeff. $=-0.331, p=0.009$ ) and a positive correlation with high levels of hs-CRP (coeff. = $0.338, p=0.015$ ), BOP (coeff. $=0.254, p=0.021$ ), PD (coeff. $=0.214, \mathrm{p}=0.015)$, CAL (coeff. $=0.411, \mathrm{p}<0.001)$, and PI (coeff. 0.412, $p=0.039$ ) (Fig. 3).

Moreover, hs-CRP resulted positively correlated with serum $\left(\mathrm{r}_{\mathrm{s}}=0.247, \mathrm{p}<0.001\right)$ and salivary $A$. actinomycetemcomitans IgG $\left(\mathrm{r}_{\mathrm{s}}=0.284, \mathrm{p}<0.001\right)$ (Fig. 4$)$.

The p-trend obtained with the Jonckheere-Terpstra test showed that there was a significant decrease in the number of teeth in the four quartiles of serum A. actinomycetemcomitans IgG (P-trend $<0.001)$, while there was a proportional increase in in CAL (P-trend $=0.004), \mathrm{PD}$ (P-trend $<0.001$ ), and $\mathrm{BOP}(\mathrm{P}$-trend $=0.003)$ (Fig. 5), while there was no significant $\mathrm{p}$-trend for PI (P-trend $=0.089)$. The JonckheereTerpstra test, instead, showed that there was no significant p-trend in quartiles of salivary $A$. actinomycetemcomitans IgG, for the number of teeth (P-trend $=0.189$ ) and for any periodontal parameter analyzed, such as $\mathrm{PD}$ (P-trend = $0.251)$, CAL (P-trend $=0.339)$, BOP (P-trend $=0.556)$ and PI (P-trend $=0.412)$ (data not shown).

The stepwise multivariate regression analysis highlighted that the number of teeth, CAL, PD, and BOP were significantly dependent on serum $A$. actinomycetemcomitans IgG ( $p<0.001$ for all parameters) (Table 3 ).

More specifically, the number of teeth was significantly dependent also on age $(p=0.029)$ and hs-CRP $(p=0.003)$; CAL was also significantly dependent on age $(p=0.034)$ and hs-CRP $(p<0.001)$. PD was significantly dependent on hsCRP $(\mathrm{p}<0.001)$; BOP was significantly dependent on age $(p=0.003)$, hs-CRP $(p<0.001)$ (Table 3$)$. The other considered confounders were not significant (data not shown).

Finally, the univariate regression analysis demonstrated that PT $(p=0.013)$, high hs-CRP $(\mathrm{p}<0.001)$ and BMI $(\mathrm{p}<$ 0.001 ) had a significant negative effect on serum $A$. actinomycetemcomitans IgG. The same predictors were found to be significant for salivary A.actinomycetemcomitans IgG (PT, $p=0.019$; hs-CRP, $\mathrm{p}<0.001$; BMI, $p=0.036$ ).

The multivariate regression analysis showed that PT $(p=0.033)$, hs-CRP $(p=0.014)$ and BMI $(p=0.017)$ were significant predictors of serum A.actinomycetemcomitans IgG while hs-CRP $(\mathrm{p}<0.001)$ and BMI $(p=0.025)$ were 
Table 1 Descriptive statistics of examined groups and comparison among them. Values are represented such as number and percentage or median and interquartile range (IQR) (1st; 3rd)

\begin{tabular}{|c|c|c|c|c|}
\hline CLINICAL FEATURES & Reference Values & $\begin{array}{l}\text { Healthy Controls } \\
(n=48)\end{array}$ & $\begin{array}{l}\text { Periodontitis } \\
(n=53)\end{array}$ & $P$-value \\
\hline Male, n. (\%) & & $23(48)$ & $26(49)$ & 0.149 \\
\hline Age, mean $\pm S D$ & & $49.4 \pm 4.6$ & $50.8 \pm 3.2$ & 0.076 \\
\hline \multicolumn{5}{|l|}{ Education level } \\
\hline Primary school, n (\%) & & $16(33.3)$ & $18(34)$ & 0.231 \\
\hline High school, n (\%) & & $17(35.4)$ & $19(35.8)$ & 0.335 \\
\hline College/University, n (\%) & & $15(31.2)$ & $16(30.2)$ & 0.089 \\
\hline $\mathrm{BMl}, \mathrm{Kg} / \mathrm{m}^{2}$, mean $\pm \mathrm{SD}$ & & $23.7 \pm 2.46$ & $24.1 \pm 2.39$ & 0.082 \\
\hline Smoker, n. (\%) & & $3(6.2)$ & $4(7.5)$ & 0.119 \\
\hline Current, n. (\%) & & $1(2)$ & $2(3.8)$ & 0.119 \\
\hline Past, n. (\%) & & $2(4.1)$ & $2(3.8)$ & - \\
\hline Never, n. (\%) & & $45(93.7)$ & $49(92.4)$ & 0.204 \\
\hline Glucose, mg/dl & $65-110$ & $115.6(89.5 ; 123.4)$ & $119.6(95.2 ; 133.4)$ & 0.324 \\
\hline $\mathrm{HbA} 1 \mathrm{c}, \mathrm{mmol} / \mathrm{mol}$ & up to 40 & $36.8(32.3 ; 38.7)$ & $37.6(30.1 ; 47.6)$ & 0.101 \\
\hline Uric acid, mg/dl & $1.9-8$ & $2(1.5 ; 2.9)$ & $2.3(1.8 ; 3.1)$ & 0.145 \\
\hline Albumin, g/L & $35-50$ & $38.6(31.1 ; 42.4)$ & $39.5(33.2 ; 41.4)$ & 0.198 \\
\hline Fibrinogen, mg/dl & $150-400$ & $278.5(223.5 ; 295.6)$ & $288.7(253.2 ; 321.2)$ & 0.047 \\
\hline Apolipoprotein A, mg/dl & $>120-140$ & $134.2(123.5 ; 132.5)$ & $136.5(129.3 ; 143.2)$ & 0.442 \\
\hline Total cholesterol, mg/dl & $<200$ & 177.6 (166.4: 184.4) & $180.4(158.4 ; 198.4)$ & 0.456 \\
\hline HDL-cholesterol, mg/dl & $<40-60$ & $48.5(47.9 ; 59.4)$ & $53.8(47.4 ; 59.7)$ & 0.511 \\
\hline LDL-Cholesterol mg/dl & $<100-130$ & $115.8(109.8 ; 128.8)$ & $119.8(108.2 ; 126.5)$ & 0.532 \\
\hline $\mathrm{BUN}, \mathrm{mg} / \mathrm{dl}$ & $7-30$ & $26.7(24.6 ; 29.8)$ & $28.7(25.6 ; 33.8)$ & 0.210 \\
\hline hs-CRP, mg/dl & $<0.8$ & $0.36(0.28 ; 0.41)$ & $0.58(0.37 ; 0.69)$ & $<0.001$ \\
\hline Systolic pressure, mm/hg & $110-130$ & $117.4(111.7 ; 128.2)$ & $123.6(117.6 ; 133.2)$ & 0.359 \\
\hline Diastolic pressure, mm/hg & $70-85$ & $81.9(74.5 ; 85.6)$ & $83.6(76.4 ; 85.8)$ & 0.111 \\
\hline Ferritin, ng/ml & $12-300$ & $77.6(72.4 ; 83.9)$ & $81.4(74.5 ; 86.1)$ & 0.786 \\
\hline \multicolumn{5}{|l|}{ Serum antibody levels, EU } \\
\hline A. actinomycetemcomitans $\lg \mathrm{A}$ & & $1.37(0.9-1.8)$ & $1.89(1.2-2.2)$ & 0.022 \\
\hline A. actinomycetemcomitans lgG & & $2.18(1.8-2.1)$ & $2.96(2.1-3.7)$ & $<0.001$ \\
\hline \multicolumn{5}{|l|}{ Salivary antibody levels, EU } \\
\hline A. actinomycetemcomitans $\lg \mathrm{A}$ & & $1.42(0.9-1.6)$ & $1.67(1.4-2.1)$ & 0.019 \\
\hline A. actinomycetemcomitans lgG & & $1.84(1.4-2)$ & $2.19(1.8-2.5)$ & 0.028 \\
\hline
\end{tabular}

Table 2 Descriptive statistics of periodontal parameters of examined groups and comparison among them. Values are represented, such as median and interquartile range (IQR) (1st; 3rd)

\begin{tabular}{llll}
\hline PERIODONTAL INDEXES & Controls $(\mathbf{n}=\mathbf{4 8})$ & Periodontitis $(\mathbf{n}=\mathbf{5 3})$ & P-value \\
\hline Number of teeth, $\mathrm{n}$. & $23.8(19-27)$ & $18.9(16-23)$ & $<0.001$ \\
CAL, mm & $1.39(1.21-1.76)$ & $3.78(3.5-4.1)$ & $<0.001$ \\
Sites with CAL 4-5 mm, \% & - & $38.6(36.5-41.2)$ & - \\
Sites with CAL $\geq 6 \mathrm{~mm}, \%$ & - & $24.5(22.6-26.1)$ & - \\
PD, mm & $1.58(1.21-2.24)$ & $4.23(3.55-4.87)$ & $<0.001$ \\
Sites with PD 4-5 mm, \% & - & $41.2(38.1-43.2)$ & - \\
Sites with PD $\geq 6$ mm, \% & - & $26.8(23.4-28.7)$ & - \\
BOP, \% & $13.2(9.1-17.7)$ & $44.1(38.2-47.4)$ & $<0.001$ \\
Plaque Index (PI), score & $0.65(0.51-0.72)$ & $0.71(0.63-0.83)$ & 0.108 \\
\hline
\end{tabular}



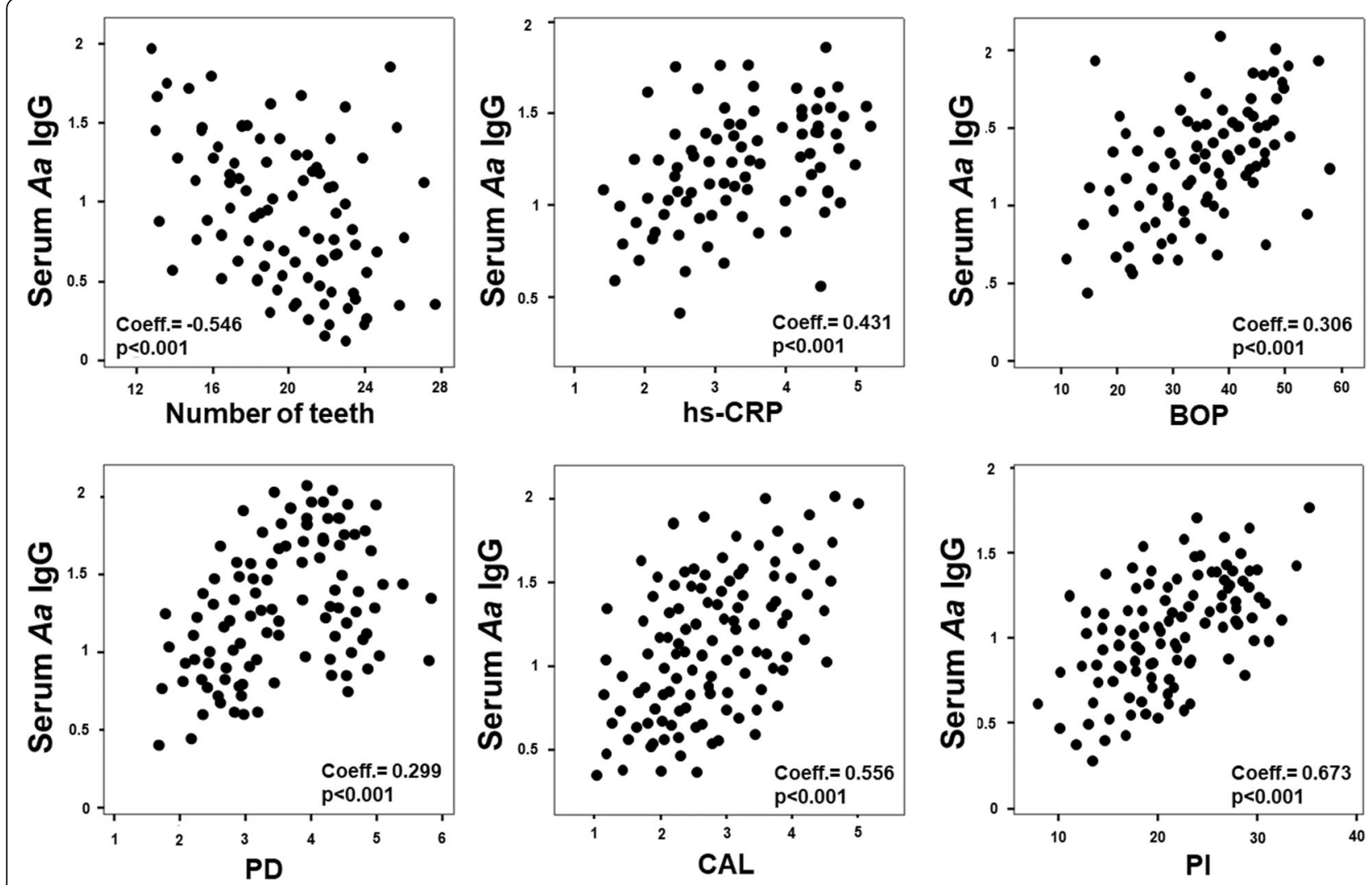

Fig. 2 Spearman Correlation among serum A. actinomycetemcomitans lgG, hs-CRP and periodontal parameters

the significant predictors of salivary A. actinomycetemcomitans IgG (Table 4).

\section{Discussion}

The present study analyzed the association between serum and salivary IgG antibodies against $A$. actinomycetemcomitans and PT. Furthermore, was evaluated the impact of PT and gingival health on serum and salivary levels of $A$. actinomycetemcomitans IgG, as these were the main confounders that could determine a significant influence in healthy subjects and PT patients. The results highlighted that patients with PT presented significantly higher serum and salivary A. actinomycetemcomitans IgG in comparison to healthy subjects.

In agreement with our results, previous studies showed that patients with PT had significantly higher serum $A$. actinomycetemcomitans IgG than healthy patients [23, 24].

In this regard, some reports showed the central role of A. actinomycetemcomitans, together with some others periodontal pathogens, in the etiology and progression of PT [25] and to be more prevalent in active sites with PT compared with non-diseased sites in the same patients [26]. A. actinomycetemcomitans has been identified between the major periodontal pathogens involved in the juvenile forms of PT [27] and decrease slightly with advancing age [15, 28]. However, recent evidences has shown a bacterial burden and prevalence of $A$. actinomycetemcomitans in the onset of aggressive and adult forms of PT, whereas the subgingival microbiota tends to shift toward red-complex pathogens as the disease progresses and related inflammatory response [20, 29-31].

Furthermore, it has also been demonstrated that $A$. actinomycetemcomitans strains could predict, in the early stages, the appearance of PT and that serum titer Ig antibodies against $A$. actinomycetemcomitans could be helpful in evaluating the degree of PT, with a greater possibility to develop tissue destruction compared to periodontal sites which don't harbour A. actinomycetemcomitans [32] since they remain remarkably stable over a long period of time $[15,33]$.

In our study, serum and salivary IgG antibodies against $A$. actinomycetemcomitans were correlated with the extent and degree of the disease in PT patients (PD, CAL, $\mathrm{BOP}$ and the number of teeth). In accordance, recent evidence has shown that serum IgG against A. actinomycetemcomitans could also have a role in the pathogenesis of PT through a specific pathway in association with different cytokines that finally determines the destruction of collagen in periodontal tissues finally [31]. 

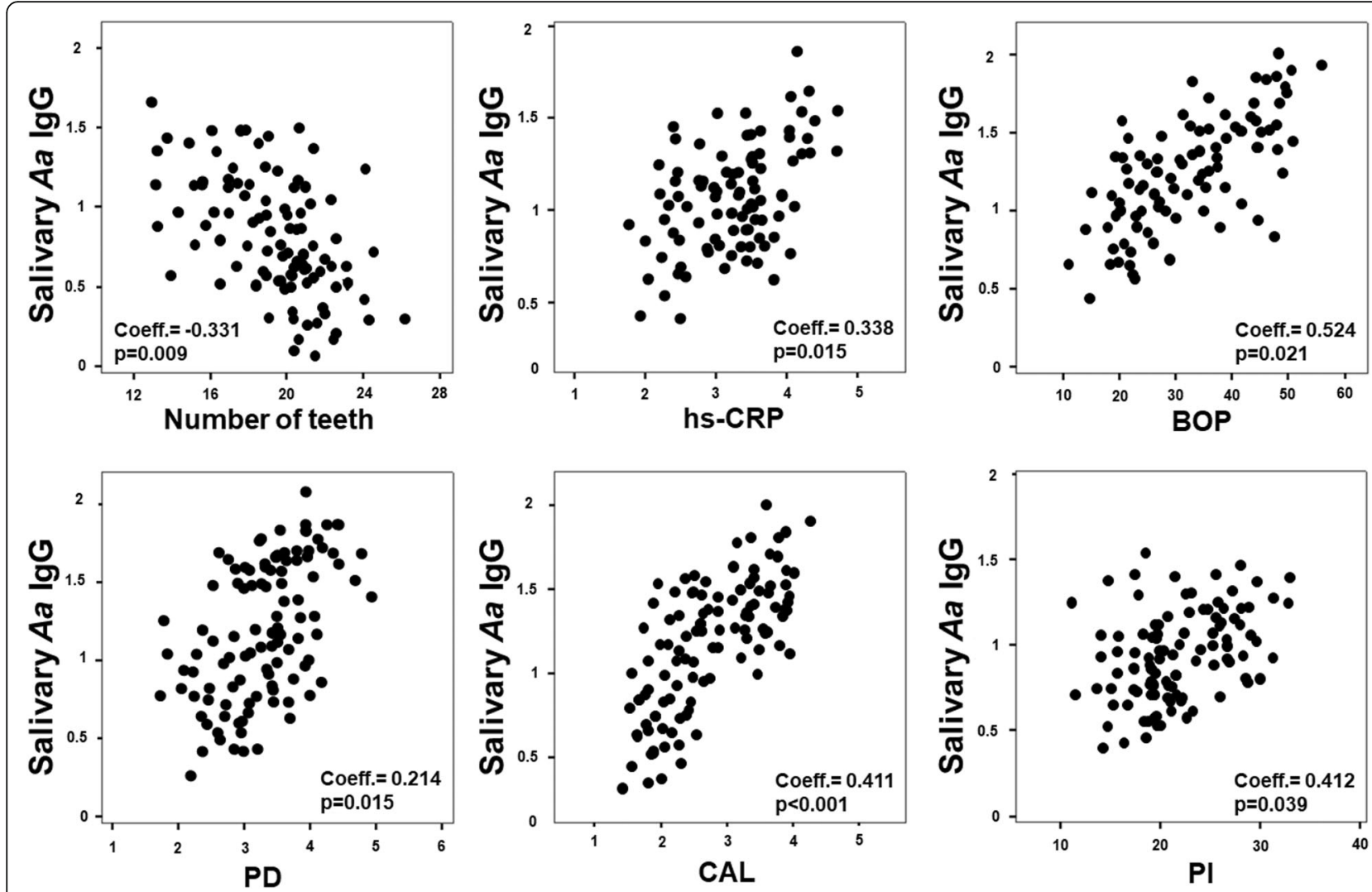

Fig. 3 Spearman Correlation among salivary A. actinomycetemcomitans IgG, hs-CRP and periodontal parameters

Recent evidence introduced the hypothesis that high IgG antibodies against A. actinomycetemcomitans could lead to an increase in the autoimmune and inflammatory systemic response, especially during PT [20, 34, 35]. Previous studies, carried out in both animal and human models, have shown that high serum IgG A. actinomycetemcomitans antibodies levels are associated to a higher risk of developing alveolar bone and tooth loss [9, 15, $36,37]$. In this regard, it is reasonable to speculate that analysis of serum IgG antibodies could be valid markers for exposure to periodontal pathogens in the long-term period $[15,33]$. Specifically, Lakio et al. have shown that serum $P$. gingivalis IgG antibodies level and A. actinomycetemcomitans IgG antibody level were particularly
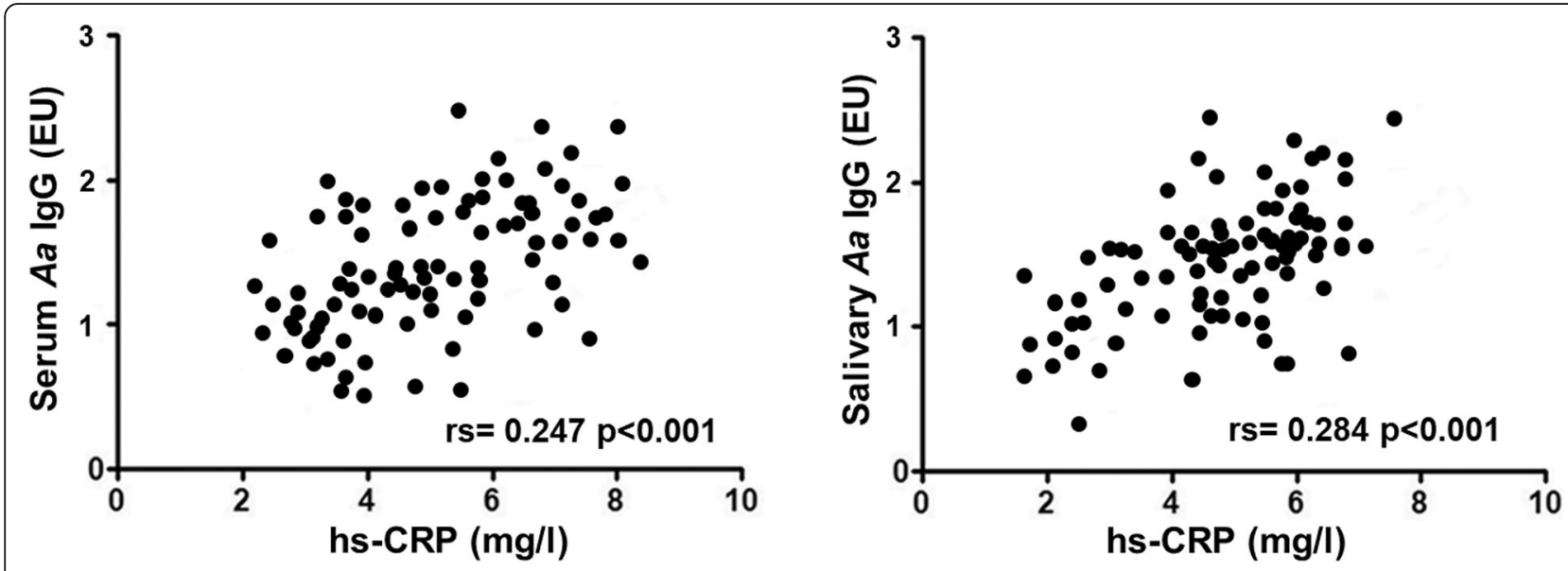

Fig. 4 Correlation analysis of serum and salivary A. actinomycetemcomitans IgG levels with hs-CRP 

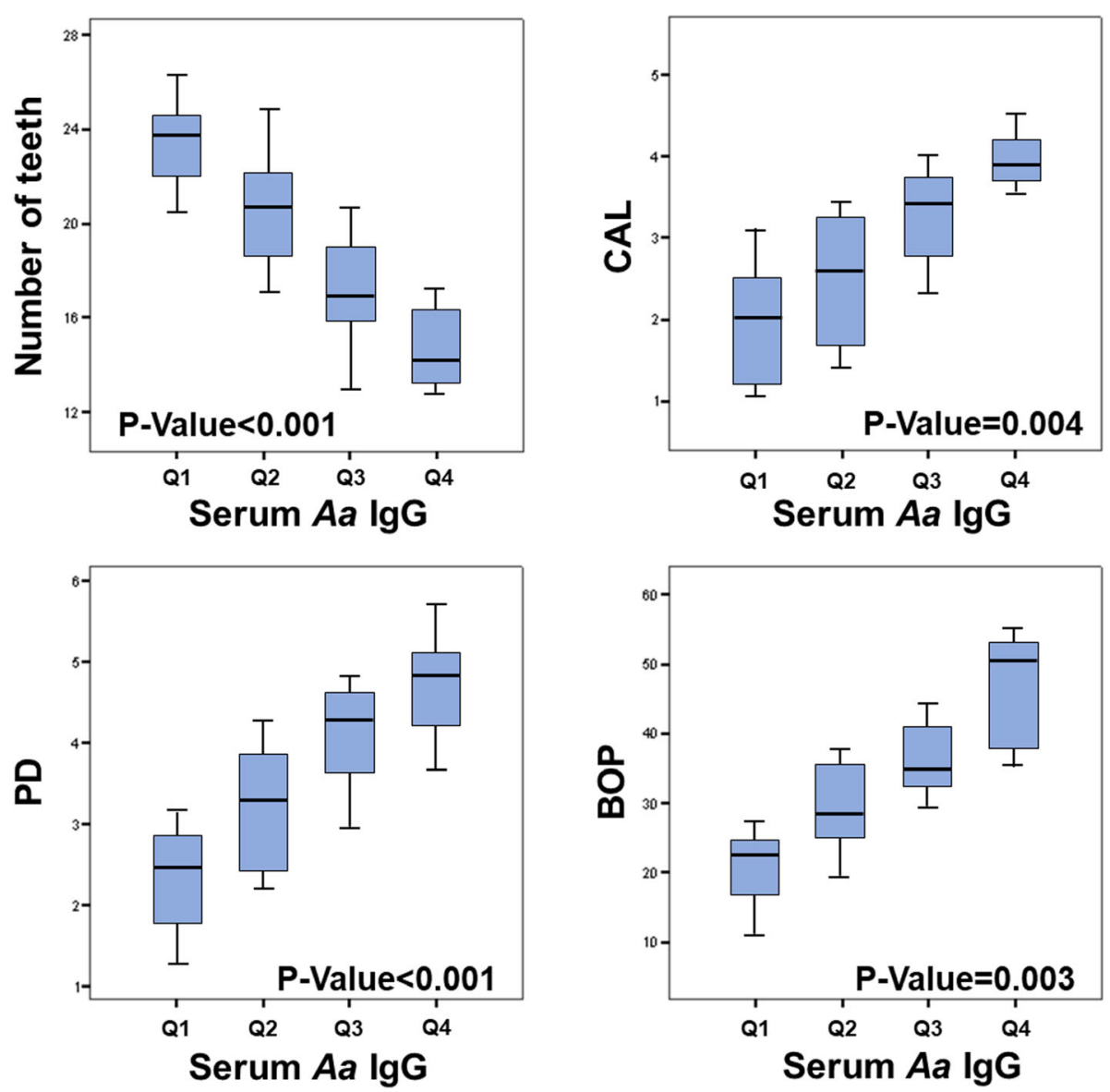

Fig. 5 Analysis of periodontal parameters according to A. actinomycetemcomitans IgG quartiles and P-trend. Each P-trend value, referred to an increase/decrease of periodontal parameters according to A. actinomycetemcomitans lgG quartiles and was obtained by means of the Jonckheere-Terpstra test for the ordered alternative hypothesis

stable over fifteen years in patients with PT, associated with the extent of PT [16]. In accordance, the present study showed that, in enrolled patients, the number of teeth and the levels of PD, CAL and BOP were significantly dependent on serum A. actinomycetemcomitans IgG antibody levels $(p<0.001$ for all observations).
These results were in agreement with previous pivotal observations which highlighted a possible relationship between $\mathrm{PT}$ and high $A$. actinomycetemcomitans levels in gingival biofilm [38].

Therefore, based on these preliminary observations, the present study was aimed at further analyzing the

Table 3 Stepwise (backward elimination) linear regression models for periodontal parameters. Only significantly predictors in the final models were reported

\begin{tabular}{|c|c|c|c|c|c|c|}
\hline \multirow[b]{2}{*}{ VARIABLES } & \multicolumn{3}{|c|}{ Number of teeth } & \multicolumn{3}{|l|}{ CAL } \\
\hline & Coeff. & 95\%C.I. & P-value & Coeff. & 95\%C.I. & P-value \\
\hline Age & -0.25 & $-0.22 ; 0.06$ & 0.029 & 0.14 & $0.02 ; 0.57$ & 0.034 \\
\hline Serum A.actinomycetemcomitans lgG & -0.27 & $-0.11 ; 0.51$ & $<0.001$ & 0.24 & $-0.05 ; 0.83$ & $<0.001$ \\
\hline \multirow[t]{2}{*}{ hs-CRP } & -1.66 & $-1.15 ;-1.19$ & 0.003 & 0.43 & $0.41 ; 0.76$ & $<0.001$ \\
\hline & \multicolumn{3}{|l|}{ PD } & \multicolumn{3}{|l|}{ BOP } \\
\hline VARIABLES & Coeff. & 95\%C.I. & $\mathrm{P}$-value & Coeff. & 95\%C.I. & P-value \\
\hline Age & -0.28 & $-0.12 ; 0.34$ & 0.075 & 0.24 & $0.11 ; 1.78$ & 0.003 \\
\hline Serum A.actinomycetemcomitans lgG & 0.16 & $0.11 ; 0.76$ & $<0.001$ & 1.44 & $1.29 ; 3.12$ & $<0.001$ \\
\hline hs-CRP & 0.51 & $0.25 ; 0.87$ & $<0.001$ & 5.13 & $3.97 ; 6.81$ & $<0.001$ \\
\hline
\end{tabular}


Table 4 Uni and multivariate linear regression analysis for serum and salivary A.actinomycetemcomitans IgG in all patients. Age was included as continuous variable. For PT, controls served as reference. For gender, male served as reference. SES, socioeconomic status; BMI, PT, periodontitis

\begin{tabular}{|c|c|c|c|c|c|c|c|}
\hline & \multirow[t]{2}{*}{ Variable } & \multicolumn{3}{|c|}{ Univariate model } & \multicolumn{3}{|c|}{ Multivariate model } \\
\hline & & B & $95 \% \mathrm{Cl}$ & $P$ & B & $95 \% \mathrm{Cl}$ & $P$ \\
\hline \multirow{11}{*}{$\begin{array}{l}\text { Serum } A \text {. actinomycetemcomitans } \\
\text { IgG levels }\end{array}$} & Age (years) & -0.045 & $-0.125 ; 0.155$ & 0.236 & -0.112 & $-0.118 ; 0.412$ & 0.554 \\
\hline & Male gender & 0.312 & $-0.101 ; 0.419$ & 0.345 & 0.327 & $-0.332 ; 0.412$ & 0.055 \\
\hline & Education & -0.041 & $-0.198 ; 0.289$ & 0.187 & -0.085 & $-0.318 ; 0.289$ & 0.498 \\
\hline & SES & 0.185 & $-0.122 ; 0.296$ & 0.396 & 0.219 & $-0.231 ; 0.155$ & 0.254 \\
\hline & Smoking & 0.174 & $-0.029 ; 0.321$ & 0.258 & 0.156 & $-0.147 ; 0.187$ & 0.199 \\
\hline & Triglycerides & 0.136 & $-0.111 ; 0.365$ & 0.221 & 0.129 & $-0.105 ; 0.321$ & 0.187 \\
\hline & LDL Cholesterol & 0.158 & $0.096 ; 0.254$ & 0.155 & 0.115 & $-0.123 ; 0.221$ & 0.069 \\
\hline & HDL Cholesterol & 0.141 & $0.116 ; 0.365$ & 0.134 & 0.108 & $-0.085 ; 0.344$ & 0.075 \\
\hline & PT & 0.298 & $0.212 ; 0.478$ & 0.013 & 0.315 & $-0.041 ; 0.458$ & 0.033 \\
\hline & hs-CRP & 0.419 & $0.029 ; 0.652$ & $<0.001$ & 0.374 & $0.157 ; 0.336$ & 0.014 \\
\hline & BMI & 0.321 & $0.96 ; 0.441$ & $<0.001$ & 0.254 & $0.125 ; 0.452$ & 0.017 \\
\hline \multirow{12}{*}{$\begin{array}{l}\text { Salivary A. actinomycetemcomitans } \\
\text { lgG levels }\end{array}$} & Age (years) & -0.112 & $-0.021 ; 0.112$ & 0.335 & 0.048 & $-0.047 ; 0.178$ & 0.551 \\
\hline & Male gender & 0.187 & $-0.155 ; 0.289$ & 0.214 & 0.098 & $-0.058 ; 0.410$ & 0.554 \\
\hline & Education & -0.145 & $-0.189 ; 0.113$ & 0.412 & -0.074 & $-0.023 ; 0.201$ & 0.328 \\
\hline & SES & 0.211 & $-0.099 ; 158$ & 0.321 & 0.055 & $0.022 ; 0.211$ & 0.352 \\
\hline & Smoking & 0.158 & $-0.254 ; 0.078$ & 0.258 & 0.147 & $-0.052 ; 0.256$ & 0.214 \\
\hline & Triglycerides & 0.289 & $-0.187 ; 0.554$ & 0.654 & 0.369 & $-0.056 ; 0.441$ & 0.551 \\
\hline & LDL Cholesterol & 0.199 & $-0.025 ; 0.325$ & 0.294 & 0.211 & $0.058 ; 0.351$ & 0.234 \\
\hline & HDL Cholesterol & 0.174 & $-0.078 ; 0.365$ & 0.551 & 0.089 & $0.027 ; 0.169$ & 0.337 \\
\hline & PT & 0.158 & $-0.045 ; 0.336$ & 0.019 & 0.033 & $-0.112 ; 0.245$ & 0.141 \\
\hline & hs-CRP & 0.096 & $0.045 ; 0.214$ & $<0.001$ & 0.047 & $0.039 ; 0.158$ & $<0.001$ \\
\hline & BMI & 0.113 & 0.058;0.199 & 0.036 & 0.058 & $0.078 ; 0.201$ & 0.025 \\
\hline & $\begin{array}{l}\text { Serum A. actinomycetemcomitans } \\
\text { lgG levels }\end{array}$ & 0.141 & $-0.117 ; 0.421$ & 0.189 & -0.116 & $-0.147 ; 0.278$ & 0.258 \\
\hline
\end{tabular}

relationship between serum and salivary A. actinomycetemcomitans IgG levels and PT and the effects exerted by $\mathrm{PT}$ and gingival health on serum and salivary $A$. actinomycetemcomitans IgG levels.

In light of this, interestingly, the results of the present study showed that, in the analyzed sample, there was a significant decrease in the number of teeth in the four quartiles of serum A. actinomycetemcomitans IgG, while there was a significant proportional increase in CAL, $\mathrm{PD}$, and BOP. Moreover, the multivariate regression analysis showed that PT, hs-CRP and BMI were significant predictors of serum A.actinomycetemcomitans IgG while hs-CRP and BMI were the significant predictors of salivary A. actinomycetemcomitans IgG, confirming the hypothesis that PT may have a negative influence on serum and salivary A. actinomycetemcomitans IgG levels. In agreement, previous researchers have shown that in patients who had high serotype frequency antibody titers of A. actinomycetemcomitans IgG (from 28 to 23\%) have a net risk of developing PT [39]. Furthermore, other reports have highlighted that patients with optimal low levels of serum A. actinomycetemcomitans IgG and IgA titers may represent a good chanced having better gingival health conditions associated with low levels of interleukin (IL)-1 $\beta$ and IL-10, tissue-destruction mediators during PT and coronary diseases [40-43].

Furthermore, the present study also suggested that serum hs-CRP were positively correlated with serum and salivary A. actinomycetemcomitans IgG levels and also that, together with PT and BMI, was a significant negative predictor of both serum and salivary A. actinomycetemcomitans IgG.

Some of the major issues associated with PT were the tissue hypoxia, oxidative stress and relative vasospasm which in turn, determines increased coagulation and endothelial injury, damage of vascular endothelial cells, and finally periodontal tissue destruction [44]. Consequently, some evidence has been suggested that periodontal infection mediated by some pathogens such as A. actinomycetemcomitans may accelerate PT and 
endothelial damage and inflammatory response orchestrated through oxidative stress pathways $[45,46]$, especially in obese patients [47]. In this respect, some evidence has shown that the tissue damage associated with PT was due to oxidative stress and, therefore, associated with high levels of nitric oxide (NO) and hs-CRP [48]. The high production and release of both oral and salivary of both hs-CRP and NO can be deduced from the demonstrated evidence that NO is released orally following the host's specific defence immune response on the infection triggered by periodontal pathogens that are exacerbated during PT $[49,50]$ and that could led to an increase of local and systemic A. actinomycetemcomitans IgG levels.

Moreover, it has been previously underlined the characteristics of $A$. actinomycetemcomitans IgG titers in the influence the inflammatory response, have previously been underlined and may interfere on the systemic release of hsCRP [51-53]. On another hand, the association between $A$. actinomycetemcomitans IgG antibodies, hs-CRP and PT could be explained by a strong influence exerted by PT on systemic inflammation, which could determine a further release of hs-CRP systemically [54]. In accordance with this hypothesis, previous studies [55-57], have demonstrated that hs-CRP levels were negatively correlated, in a dosedependent manner, with periodontal inflammation in patients with PT, even after adjustment for potential confounders [58]. On this regard the presence of PT has been demonstrate to determine a further systemic inflammation and augmented risk of endothelial dysfunction [10, 59-61].

The present study has some limitations, such as the study design. The cross-sectional nature of the study design does not allow to a better analysis of the longitudinal relationship between PT and serum $A$. actinomycetemcomitans IgG titers. Moreover, staging the different severity levels of PT at baseline could have better-stratified patients.

\section{Conclusions}

During the last few decades, a number of trials have tried to analyze the impact of IgG A. actinomycetemcomitans titers for human health and related diseases. The results of the present study indicated that PT patients presented higher serum and salivary A. actinomycetemcomitans IgG titers compared to healthy subjects. Moreover, PT and high hs-CRP were negative predictors of high levels of serum and salivary A. actinomycetemcomitans IgG titers. With regard to this, the results of this study suggest that PT may have led to a negative effect in serum and salivary A. actinomycetemcomitans IgG titers. However, further studies with a more large sample and different design are needed in order to analyze the role of A. actinomycetemcomitans IgG titers in PT patients better.

\section{Supplementary information}

Supplementary information accompanies this paper at https://doi.org/10. 1186/s12903-020-01258-5.

Additional file 1. STROBE Checklist.

\section{Abbreviations}

lg: Immunoglobulin; A: actinomycetemcomitans: Aggregatibacter actinomycetemcomitans; HC: healthy controls; PT: periodontitis; hs-CRP: highsensitivity c-reactive protein; $\mathrm{P}$. gingivalis: Porphyromonas gingivalis; BOP: bleeding on probing; PD: probing depth; CAL: clinical attachment level; BMI: body mass index; PI: plaque score; ICC: intraclass correlation coefficient

\section{Acknowledgements}

Not applicable.

\section{Authors' contributions}

G.l. conceived the idea and wrote the paper. G.I., A.P., R.P., S.F. and A.A. reviewed the collected data. G.I. and G.P. were responsible for editing, original data and text preparation. All authors took responsibility for the integrity of the data that is present in this study. The authors read and approved the final manuscript.

\section{Funding}

This work was carried out with funding by the Department of General Surgery and Surgical-Medical Specialties, School of Dentistry, University of Catania, Italy.

\section{Availability of data and materials}

The datasets used and/or analysed during the current study available from the corresponding author on reasonable request.

\section{Ethics approval and consent to participate}

The study was performed by the Declaration of Helsinki, revised in 2016 on medical research. Ethical approval was obtained by the IRB of the University of Messina (\#12-16). Written informed consent was obtained from each patient about the study characteristics and possible risks of the study.

Consent for publication

Not applicable.

\section{Competing interests}

The authors declare that they have no conflicts of interest in the present study.

\section{Author details}

${ }^{1}$ Department of General Surgery and Surgical-Medical Specialties, School of Dentistry, University of Catania, Via S. Sofia 78, 95124 Catania, Italy.

${ }^{2}$ Fondazione Policlinico Universitario A. Gemelli IRCCS, Institute of Dentistry and Maxillofacial Surgery, Università Cattolica del Sacro Cuore, 00168 Rome, Italy. ${ }^{3}$ Department of Economical, Business and Environmental Sciences and Quantitative Methods, University of Messina, Messina, Italy.

Received: 8 June 2020 Accepted: 21 September 2020

Published online: 15 October 2020

\section{References}

1. Bartold PM. Lifestyle and periodontitis: The emergence of personalized periodontics. Periodontol 2000. 2018;78(1):7-11.

2. Masumoto R, Kitagaki J, Fujihara C, Matsumoto M, Miyauchi S, Asano Y, Imai A, Kobayashi K, Nakaya A, Yamashita M, et al. Identification of genetic risk factors of aggressive periodontitis using genomewide association studies in association with those of chronic periodontitis. J Periodontal Res. 2019;54(3): 199-206.

3. Isola G, Polizzi A, Alibrandi A, Indelicato F, Ferlito S. Analysis of Endothelin-1 concentrations in individuals with periodontitis. Sci Rep. 2020;10(1):1652.

4. Toker H, Balci Yuce H, Lektemur Alpan A, Gevrek F, Elmastas M. Morphometric and histopathological evaluation of the effect of grape seed proanthocyanidin on alveolar bone loss in experimental diabetes and periodontitis. J Periodontal Res. 2018;53(3):478-86. 
5. Kim OS, Shin MH, Kweon SS, Lee YH, Kim OJ, Kim YJ, Chung HJ. The severity of periodontitis and metabolic syndrome in Korean population: the donggu study. J Periodontal Res. 2018;53(3):362-8.

6. Tonetti MS, Greenwell H, Kornman KS. Staging and grading of periodontitis: framework and proposal of a new classification and case definition. J Periodontol. 2018;89(Suppl 1):S159-72.

7. Damgaard C, Reinholdt J, Enevold C, Fiehn NE, Nielsen CH, Holmstrup P. Immunoglobulin $\mathrm{G}$ antibodies against Porphyromonas gingivalis or Aggregatibacter actinomycetemcomitans in cardiovascular disease and periodontitis. J Oral Microbiol. 2017;9(1):1374154.

8. Kinane DF, Mooney J, Ebersole JL. Humoral immune response to Actinobacillus actinomycetemcomitans and Porphyromonas gingivalis in periodontal disease. Periodontol 2000. 1999;20:289-340.

9. Ebbers M, Lubcke PM, Volzke J, Kriebel K, Hieke C, Engelmann R, Lang H, Kreikemeyer B, Muller-Hilke B. Interplay between P. gingivalis, F. nucleatum and $\mathrm{A}$. actinomycetemcomitans in murine alveolar bone loss, arthritis onset and progression. Sci Rep. 2018;8(1):15129.

10. Patini R, Cattani P, Marchetti S, Isola G, Quaranta G, Gallenzi P. Evaluation of predation capability of periodontopathogens bacteria by bdellovibrio bacteriovorus HD100. An in Vitro Study. Materials. 2019;12(12):2008.

11. Chung J, Kim S, Lee HA, Park MH, Kim S, Song YR, Na HS. Trans-cinnamic aldehyde inhibits Aggregatibacter actinomycetemcomitans-induced inflammation in THP-1-derived macrophages via autophagy activation. J Periodontol. 2018;89(10):1262-71.

12. Liljestrand JM, Paju S, Pietiainen M, Buhlin K, Persson GR, Nieminen MS, Sinisalo J, Mantyla P, Pussinen PJ. Immunologic burden links periodontitis to acute coronary syndrome. Atherosclerosis. 2018;268:177-84.

13. Colhoun HM, Slaney JM, Rubens MB, Fuller JH, Sheiham A, Curtis MA. Antibodies to periodontal pathogens and coronary artery calcification in type 1 diabetic and nondiabetic subjects. J Periodontal Res. 2008;43(1):10310.

14. Ogrendik M, Kokino S, Ozdemir F, Bird PS, Hamlet S. Serum antibodies to oral anaerobic bacteria in patients with rheumatoid arthritis. MedGenMed. 2005; $7(2): 2$.

15. Papapanou PN, Neiderud AM, Disick E, Lalla E, Miller GC, Dahlen G. Longitudinal stability of serum immunoglobulin $\mathrm{G}$ responses to periodontal bacteria. J Clin Periodontol. 2004;31(11):985-90.

16. Lakio L, Antinheimo J, Paju S, Buhlin K, Pussinen PJ, Alfthan G. Tracking of plasma antibodies against Aggregatibacter actinomycetemcomitans and Porphyromonas gingivalis during 15 years. J Oral Microbiol. 2009;1. https:// doi.org/10.3402/jom.v1i0.1979.

17. Morozumi T, Nakagawa T, Nomura Y, Sugaya T, Kawanami M, Suzuki F, Takahashi K, Abe Y, Sato S, Makino-Oi A, et al. Salivary pathogen and serum antibody to assess the progression of chronic periodontitis: a 24-mo prospective multicenter cohort study. J Periodontal Res. 2016;51 (6):768-78.

18. Isola G, Matarese G, Ramaglia L, Pedulla E, Rapisarda E, lorio-Siciliano V. Association between periodontitis and glycosylated haemoglobin before diabetes onset: a cross-sectional study. Clin Oral Investig. 2020;24(8):2799808.

19. O'Leary TJ, Drake RB, Naylor JE. The plaque control record. J Periodontol. 1972:43(1):38.

20. Gadekar NB, Hosmani JV, Bhat KG, Kotrashetti VS, Nayak RS, Babji DV, Pattanshetty SM, Joshi VM, Bansode RA. Detection of antibodies against Aggregatibacter actinomycetemcomitans in serum and saliva through ELISA in periodontally healthy individuals and individuals with chronic periodontitis. Microb Pathog. 2018;125:438-42.

21. Pussinen PJ, Kononen E, Paju S, Hyvarinen K, Gursoy UK, Huumonen S, Knuuttila M, Suominen AL. Periodontal pathogen carriage, rather than periodontitis, determines the serum antibody levels. J Clin Periodontol. 2011;38(5):405-11.

22. Pussinen PJ, Vilkuna-Rautiainen T, Alfthan G, Mattila K, Asikainen S. Multiserotype enzyme-linked immunosorbent assay as a diagnostic aid for periodontitis in large-scale studies. J Clin Microbiol. 2002;40(2):512-8.

23. Guentsch A, Puklo M, Preshaw PM, Glockmann E, Pfister W, Potempa J, Eick S. Neutrophils in chronic and aggressive periodontitis in interaction with Porphyromonas gingivalis and Aggregatibacter actinomycetemcomitans. J Periodontal Res. 2009:44(3):368-77.

24. Ideguchi H, Yamashiro K, Yamamoto T, Shimoe M, Hongo S, Kochi S, Yoshihara-Hirata C, Aoyagi H, Kawamura M, Takashiba S. Molecular imaging assessment of periodontitis lesions in an experimental mouse model. Clin Oral Investig. 2019;23(2):821-7.
25. Teles R, Sakellari D, Teles F, Konstantinidis A, Kent R, Socransky S, Haffajee A. Relationships among gingival crevicular fluid biomarkers, clinical parameters of periodontal disease, and the subgingival microbiota. J Periodontol. 2010; 81(1):89-98.

26. Riviere GR, Smith KS, Tzagaroulaki E, Kay SL, Zhu X, DeRouen TA, Adams DF. Periodontal status and detection frequency of bacteria at sites of periodontal health and gingivitis. J Periodontol. 1996;67(2):109-15.

27. Zambon JJ. Actinobacillus actinomycetemcomitans in human periodontal disease. J Clin Periodontol. 1985;12(1):1-20.

28. Papapanou PN, Neiderud AM, Papadimitriou A, Sandros J, Dahlen G. "Checkerboard" assessments of periodontal microbiota and serum antibody responses: a case-control study. J Periodontol. 2000;71(6):885-97.

29. Cortelli JR, Cortelli SC, Jordan S, Haraszthy VI, Zambon JJ. Prevalence of periodontal pathogens in Brazilians with aggressive or chronic periodontitis. J Clin Periodontol. 2005:32(8):860-6.

30. Heller D, Silva-Boghossian CM, do Souto RM, Colombo AP. Subgingival microbial profiles of generalized aggressive and chronic periodontal diseases. Arch Oral Biol. 2012;57(7):973-80.

31. Lee HA, Park MH, Song Y, Na HS, Chung J. Role of Aggregatibacter actinomycetemcomitans-induced autophagy in inflammatory response. J Periodontol. 2020. https://doi.org/10.1002/JPER.19-0639. Online ahead of print.

32. Li X, Zhou L, Takai H, Sasaki Y, Mezawa M, Li Z, Wang Z, Yang L, Wang S, Matsumura $\mathrm{H}$, et al. Aggregatibacter actinomycetemcomitans lipopolysaccharide regulates bone sialoprotein gene transcription. J Cell Biochem. 2012;113(9):2822-34.

33. Alfakry H, Paju S, Sinisalo J, Nieminen MS, Valtonen V, Saikku P, Leinonen M, Pussinen PJ. Periodontopathogen- and host-derived immune response in acute coronary syndrome. Scand J Immunol. 2011;74(4):383-9.

34. Furuichi $Y$, Shimotsu A, Ito H, Namariyama $Y$, Yotsumoto $Y$, Hino $Y$, Mishige $Y$, Inoue M, Izumi Y. Associations of periodontal status with general health conditions and serum antibody titers for Porphyromonas gingivalis and Actinobacillus actinomycetemcomitans. J Periodontol. 2003;74(10):1491-7.

35. Bizzarro S, Nicu EA, van der Velden U, Laine ML, Loos BG. Association of serum immunoglobulin $\mathrm{G}(\mathrm{lgG})$ levels against two periodontal pathogens and prothrombotic state: a clinical pilot study. Thromb J. 2010;8:16.

36. Liljestrand JM, Gursoy UK, Hyvarinen K, Sorsa T, Suominen AL, Kononen E, Pussinen PJ. Combining salivary pathogen and serum antibody levels improves their diagnostic ability in detection of periodontitis. J Periodontol. 2014;85(1):123-31.

37. Velusamy SK, Ganeshnarayan K, Markowitz K, Schreiner H, Furgang D, Fine $\mathrm{DH}$, Velliyagounder K. Lactoferrin knockout mice demonstrates greater susceptibility to Aggregatibacter actinomycetemcomitans-induced periodontal disease. J Periodontol. 2013;84(11):1690-701.

38. Minguez M, Ennibi OK, Perdiguero P, Lakhdar L, Abdellaoui L, Sanchez MC, Sanz M, Herrera D. Antimicrobial susceptibilities of Aggregatibacter actinomycetemcomitans and Porphyromonas gingivalis strains from periodontitis patients in Morocco. Clin Oral Investig. 2019;23(3):1161-70.

39. Pietiainen M, Kopra KAE, Vuorenkoski J, Salminen A, Paju S, Mantyla P, Buhlin K, Liljestrand JM, Nieminen MS, Sinisalo J, et al. Aggregatibacter actinomycetemcomitans serotypes associate with periodontal and coronary artery disease status. J Clin Periodontol. 2018;45(4):413-21.

40. Trindade SC, Olczak T, Gomes-Filho IS, Moura-Costa LF, Cerqueira EM, Galdino-Neto M, Alves H, Carvalho-Filho PC, Xavier MT, Meyer R. Induction of interleukin (IL)-1 beta, IL-10, IL-8 and immunoglobulin G by Porphyromonas gingivalis HmuY in humans. J Periodontal Res. 2012;47(1): 27-32.

41. O'Brien-Simpson NM, Veith PD, Dashper SG, Reynolds EC. Antigens of bacteria associated with periodontitis. Periodontol 2000. 2004;35:101-34.

42. Lamster IB, Kaluszhner-Shapira I, Herrera-Abreu M, Sinha R, Grbic JT. Serum $\lg \mathrm{G}$ antibody response to Actinobacillus actinomycetemcomitans and Porphyromonas gingivalis: implications for periodontal diagnosis. J Clin Periodontol. 1998;25(6):510-6.

43. Akhi R, Wang C, Nissinen AE, Kankaanpaa J, Bloigu R, Paju S, Mantyla P, Buhlin K, Sinisalo J, Pussinen PJ, et al. Salivary IgA to MAA-LDL and Oral pathogens are linked to coronary disease. J Dent Res. 2019;98(3):296-303.

44. Bhattarai G, Min CK, Jeon YM, Bashyal R, Poudel SB, Kook SH, Lee JC. Oral supplementation with $\mathrm{p}$-coumaric acid protects mice against diabetesassociated spontaneous destruction of periodontal tissue. J Periodontal Res. 2019;54(6):690-701.

45. Zhu B, Macleod LC, Newsome E, Liu J, Xu P. Aggregatibacter actinomycetemcomitans mediates protection of Porphyromonas gingivalis 
from Streptococcus sanguinis hydrogen peroxide production in multispecies biofilms. Sci Rep. 2019;9(1):4944

46. Li X, Hu L, Ma L, Chang S, Wang W, Feng Y, Xu Y, Hu J, Zhang C, Wang S. Severe periodontitis may influence cementum and dental pulp through inflammation, oxidative stress, and apoptosis. J Periodontol. 2019;90(11): 1297-306.

47. Li W, Shi D, Song W, Xu L, Zhang L, Feng X, Lu R, Wang X, Meng H. A novel U-shaped relationship between BMI and risk of generalized aggressive periodontitis in Chinese: a cross-sectional study. J Periodontol. 2019;90(1): 82-9.

48. Balci Yuce H, Toker H, Yildirim A, Tekin MB, Gevrek F, Altunbas N. The effect of luteolin in prevention of periodontal disease in Wistar rats. J Periodontol. 2019;90(12):1481-9.

49. Rausch-Fan X, Matejka M. From plaque formation to periodontal disease, is there a role for nitric oxide? Eur J Clin Investig. 2001;31(10):833-5.

50. Hussain QA, McKay IJ, Gonzales-Marin C, Allaker RP. Regulation of adrenomedullin and nitric oxide production by periodontal bacteria. J Periodontal Res. 2015;50(5):650-7.

51. Rebeis ES, Albuquerque-Souza E, Paulino da Silva M, Giudicissi M, Mayer MPA, Saraiva L. Effect of periodontal treatment on Aggregatibacter actinomycetemcomitans colonization and serum IgG levels against a. actinomycetemcomitans serotypes and Omp29 of aggressive periodontitis patients. Oral Dis. 2019;25(2):569-79.

52. Thanakun S, Izumi Y. Effect of periodontitis on Adiponectin, C-reactive protein, and immunoglobulin $\mathrm{G}$ against Porphyromonas gingivalis in Thai people with overweight or obese status. J Periodontol. 2016;87(5):566-76.

53. Thanakun S, Pornprasertsuk-Damrongsri S, Gokyu M, Kobayashi H, Izumi Y. Inverse Association of Plasma IgG antibody to Aggregatibacter actinomycetemcomitans and high C-reactive protein levels in patients with metabolic syndrome and periodontitis. PLoS One. 2016;11(2):e0148638.

54. Pink C, Kocher T, Meisel P, Dorr M, Markus MR, Jablonowski L, Grotevendt A, Nauck M, Holtfreter B. Longitudinal effects of systemic inflammation markers on periodontitis. J Clin Periodontol. 2015:42(11):988-97.

55. Tsioufis C, Thomopoulos C, Soldatos N, Syrseloudis D, Kasiakogias A, Silvestros S, Stefanadi E, Mostratou E, Stefanadis C. The conjoint detrimental effect of chronic periodontal disease and systemic inflammation on asymmetric dimethyl-arginine in untreated hypertensive subjects. Atherosclerosis. 2010;208(1):258-63.

56. Isola G, Alibrandi A, Curro M, Matarese M, Ricca S, Matarese G, lentile R, Kocher T. Evaluation of salivary and serum ADMA levels in patients with periodontal and cardiovascular disease as subclinical marker of cardiovascular risk. J Periodontol. 2020;91(8):1076-84.

57. Isola G, Alibrandi A, Rapisarda E, Matarese G, Williams RC, Leonardi R. Association of vitamin $D$ in patients with periodontitis: a cross-sectional study. J Periodontal Res. 2020;55(5):602-12. https://doi.org/10.1111/jre.12746.

58. Isola G, Polizzi A, Santonocito S, Alibrandi A, Ferlito S. Expression of Salivary and Serum Malondialdehyde and Lipid Profile of Patients with Periodontitis and Coronary Heart Disease. Int J Mol Sci. 2019;20(23). https://doi.org/10. 3390/ijms20236061.

59. Zhang Z, Ma N, Zheng Y, Zhang L. Association of serum immunoglobulin-G to Porphyromonas gingivalis with acute cerebral infarction in the Chinese population. J Indian Soc Periodontol. 2015;19(6):628-32.

60. Leira Y, Rodriguez-Yanez M, Arias S, Lopez-Dequidt I, Campos F, Sobrino T, D'Aiuto F, Castillo J, Blanco J. Periodontitis is associated with systemic inflammation and vascular endothelial dysfunction in patients with lacunar infarct. J Periodontol. 2019;90(5):465-74.

61. Karatas O, Yuce HB, Tulu F, Taskan MM, Gevrek F, Toker H. Evaluation of apoptosis and hypoxia-related factors in gingival tissues of smoker and non-smoker periodontitis patients. J Periodontal Res. 2020;55(3):392-9.

\section{Publisher's Note}

Springer Nature remains neutral with regard to jurisdictional claims in published maps and institutional affiliations.

Ready to submit your research? Choose BMC and benefit from:

- fast, convenient online submission

- thorough peer review by experienced researchers in your field

- rapid publication on acceptance

- support for research data, including large and complex data types

- gold Open Access which fosters wider collaboration and increased citations

- maximum visibility for your research: over $100 \mathrm{M}$ website views per year

At BMC, research is always in progress.

Learn more biomedcentral.com/submissions 